\title{
COLONIAL LEGACIES AND COMPETING MASCULINITIES: THE SUPREME COURT OF CANADA'S RETURN TO REASON IN R. V. KAPP
}

\section{Caroline Hodes*}

This article examines a series of unarticulated gender dynamics that shaped some of the recent changes to the legal test for discrimination under s. 15 of the Canadian Charter of Rights and Freedoms. Despite the volume of literature that references R. v. Kapp, none of it has specifically addressed how race is gendered through the claims of the accused, the witnesses who testified on their behalf or the decisions of the judges who interpreted their testimony. Revisiting the legal strategies used in this case reveals ongoing challenges to accessing justice for marginalized groups and impediments to reconciliation.

Dans cet article, l'auteure s'attarde à une série d'indicateurs sexospécifiques non articulés qui ont façonné quelques-uns des changements récemment apportés au critère juridique à appliquer à l'égard de la discrimination au titre de l'article 15 de la Charte canadienne des droits et libertés. L'arrêt R. c. Kapp est abondamment cité dans la littérature. Néanmoins, aucun renvoi n'a porté explicitement sur l'interaction entre la race et le genre qui découle des allégations de l'accusé, de la version donnée par les personnes qui ont témoigné pour son compte ou des décisions des juges qui ont interprété ces témoignages. L'analyse des stratégies juridiques utilisées dans cette affaire révèle des problèmes continus liés à l'accès à la justice dans le cas des groupes marginalisés, ainsi que des obstacles à la réconciliation.

\section{INTRODUCTION}

In 1999 two pivotal things happened to transform equality rights analysis at the Supreme Court of Canada. The first was the introduction of the dignity interest into the legal test to establish whether or not discrimination had taken place in the Law v. Canada decision. ${ }^{1}$ The second was that the Court established a highly formalistic approach to the grounds requirement in equality rights cases in the Corbiere v. Canada decision. $^{2}$ These two judicial decisions were made within one year of what the lawyers who represented the commercial fishers in the R. v. Kapp case referred to as "the largest protest fishery in Canadian history." 3

R. v. Kapp was initiated by a group of commercial fishers who protested a Pilot Sales Program [PSP] that allocated communal commercial fishing licenses to First Nations who had negotiated agreements with the Department of Fisheries and Oceans Canada. They voiced their opposition to these policy measures by fishing at a prohibited time, an offence punishable by imprisonment and fines of up to one hundred

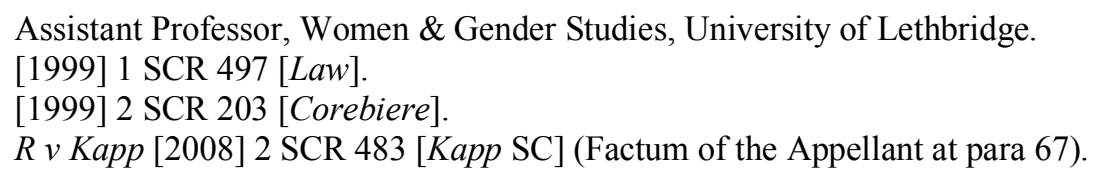


thousand dollars under the Fisheries Act. ${ }^{4}$ The BC Fisheries Survival Coalition, a non-registered group of commercial fishers who have a history of challenging government programs that aim to honour Aboriginal rights and title, not only helped to direct the litigation but they provided a significant amount of financial support for this case. This group also furthered the already visceral anti-Aboriginal rights sentiment in both political and popular discussions at the time of the initial trial.

Legal commentators and journalists have noted that the Coalition explicitly racialized discussions and debates over Aboriginal rights through their strong presence in court, their high level of visibility in the popular media and their contributions to the Parliamentary debates within the House of Commons Standing Committee on Fisheries and Oceans. ${ }^{5}$ As a result, the discursive construction of a "race-based fishery" took centre stage not only in the claims of the commercial fishers who were charged for taking part in the protest fishery, but also in the testimony of witnesses, the facta presented to the appellate court judges, the text of the judicial decisions, the popular news media, and the conclusions of the House of Commons Standing Committee. ${ }^{6}$ This occurred despite the fact that these policies were the result of nation to nation negotiations and that those who were entitled to fish during the twenty-four-hour period included diverse communities, and individuals who had been adopted into, married into and/or authorized to fish on behalf of those communities.

John Michael Kapp, the fisher after whom the case is named, was one of those arrested during the protest. The protest was organized with the deliberate intention of bringing forward an anti-discrimination claim under the equality rights provisions of the Canadian Charter of Rights and Freedoms as a defense to the charges participants knew would be laid against them. ${ }^{7}$ Although this changed several times pending the outcome of other cases that challenged similar programs on administrative grounds, the main thrust of their argument ended up being that the PSP was discriminatory because it opened the commercial salmon fishery to members of the Musqueam Band, the Tsleil-Waututh Nation (formerly the Burrard Band) and Tsawwassen First Nation for a period of twenty-four hours before the rest of the commercial fleet could access it. ${ }^{8}$ At trial, none of the accused testified but they called as witnesses fourteen people who were

RSC 1985, c F-14.

5 House of Commons, Standing Committee on Fisheries and Oceans, Minutes of Proceedings, Meeting No 31 (19 November 2001); See Andre Goldenberg, “'Salmon for Peanut Butter': Equality, Reconciliation and the Rejection of Aboriginal Fishing Rights," (2004) 3 Indigenous LJ 61 at 69-73 for an overview of media reports at the time of the 2003 decision in $R v$ Kapp. The articles cited include: G Oakes, "Judge Finds Aboriginals Only Salmon Fishery Grossly Unfair," The Lawyers Weekly, 23:14 (15 August 2003); R Mickleburgh, "Judge Declares Native Fishery Invalid" Globe and Mail (29 July 2003); R Mickleburgh, "Native-Only Salmon Fisheries Cancelled" Globe and Mail (30 July 2003); J Beatty, "Treaty Will give Natives Fishing Rights: Liberals Opposed to Separate Fisheries but Have No Choice in the Matter" Vancouver Sun (9 January 2003). More recent articulations of this discourse can be found here: C. Blatchford, "Race-based policing brings the administration of justice into disrepute on BC's Fraser River" National Post (20 December 2012); C Curry, "Poll 'crafted to support a certain response' Globe and Mail (16 July 2007); M Milke, "End B.C.'s race-based fishery" National Post (22 September 2006); K Sims, "Race-based fishing 'out of control': DFO" Vancouver Sun (19 May 2011); "Harper vows to end 'race-based fisheries”" CBC News (12 July 2006).

$6 \quad$ Ibid.

7 Canadian Charter of Rights and Freedoms, Part I of the Constitution Act, 1982, being schedule B to the Canada Act 1982 (U.K.), 1982, c. 11 [Charter].

8 Defense counsel for the commercial fishers started the trial with both the administrative issues and the Charter claim, later withdrew the Charter claim when the case was still being heard by Judge Trueman and then reintroduced the 
working in the commercial fishing industry, some of whom were accused on the same charge in parallel proceedings that were before the courts at that time. ${ }^{9}$ These defense witnesses were called to provide evidence of the overall effects of the PSP.

The Crown and a number of intervenors made considerable efforts to circumvent the racediscrimination claim. The Crown not only attempted to impeach the witnesses by questioning their reliability but they also advanced the argument that the commercial fishers were too diverse a group to plead on a single ground thereby failing to meet the grounds requirement in s. 15 Charter applications. ${ }^{10}$ Nevertheless, the Provincial Court judge relied on the Corbiere Court's test for constructively immutable characteristics to establish that these commercial fishers were a cohesive enough group that they could experience a targeted form of discrimination that was analogous to racism on account of not sharing what became the immutable characteristics of the beneficiaries of the PSP. ${ }^{11}$ On appeal, a number of First Nations and the Assembly of First Nations introduced s. 25 of the Charter as a defense to the s. 15 challenge. ${ }^{12}$ The most impactful of these submissions was the Tsawwassen First Nation's formulation of it as a protective shield that ought to have insulated a program designed as a means to further Aboriginal rights from the equality claim of the commercial fishers. ${ }^{13}$ Nevertheless, race as a singular, universal, homogenizing marker of difference was retained at the Supreme Court of Canada in order to identify the beneficiaries of the government program that was challenged in this case.

The 2008 Supreme Court ruling currently outlines the most pivotal transformations in equality rights analysis under s. 15 of the Charter since the 1999 Law v. Canada decision. The decision removed the dignity interest from s. 15(1) that had been introduced by the Law Court and granted s. 15(2) "independent status to protect ameliorative laws, programs and activities." 14 Although these transformations are significant, the Court's jurisprudence over the last fifteen years has affirmed that the Corbiere Court's focus on immutable characteristics has become a requirement for establishing grounds in Charter equality rights cases. ${ }^{15}$ Although it has been almost a decade since the Kapp decision was rendered, this case continues to influence the outcomes in equality rights cases in the present. All of these developments have been commented on extensively in the prolific amount of literature that references this case but what has remained un-noticed is the role that competing masculinities played in the deployment of race through the testimony of the commercial fishers.

Charter claim after Judge Trueman withdrew from the case on medical leave and was replaced with Judge Kitchen. See: $R v$ Kapp (2003) BCJ No 1772 BCPC [Kapp Provincial Court] (Trial Transcripts at 300-301, 719-738).

$9 \quad$ Ibid at para 87; $R$ v Kapp (2004) BCSC $958[$ Kapp BCSC] at para 48.

10 Kapp SC, supra note 3 (Factum of the Respondent, Her Majesty the Queen at para 72).

11 Kapp Provincial Court at paras 161-163.

12 Kapp SC, supra note 3 (Factum of the Intervener Assembly of First Nations; Factum of the Intervener Haisla Nation; Factum of the Interveners Heiltsuk Nation and Musqueam Indian Band; Factum of the Intervener Nee Tahi Buhn Indian Band; Factum of the Interveners Te'Mexw Nations; Factum of the Intervener Tsawwassen First Nation)

13 Kapp BCSC, supra note 9; and Kapp SC, supra note 3 (Factum of the Intervener Tsawwassen First Nation).

14 Kapp SC, supra note 3 (Reasons of the Chief Justice and Abella J at paras 27-55); Jennifer Koshan \& Jonnette Watson Hamilton, "The End of Law: A new Framework for Assessing s. 15(1) Charter Challenges" (20 February 2009) Ablawg (blog), online: < http://ablawg.ca/wp-content/uploads/2010/05/blog_jk_jwh_ermineskin_feb2009.pdf>

15 Jessica Eisen, "On Shaky Grounds: Analogous Grounds under the Charter" (2013) 2:2 Can J of Poverty L1 [Eisen, "Shaky Grounds"] at 14; See also: Withler v Canada [2011] 1 SCR 396 [Withler]. 
This article will show that these unarticulated gender dynamics played a considerable role in shaping the transformations to the legal test under s. 15(1) of the Charter. A critical examination of how the defense witness testimony was recontextualized by the judiciary in $R$. $v$. Kapp underscores the continuing relevance of Margaret Thornton, Carol Smart and Ngaire Naffine's early criticisms of legal liberalism, legal positivism and the androcentric dualisms that are at the heart of what they identify as modern western legal reasoning. ${ }^{16}$ The dualisms that Smart, Thornton and Naffine claim structure English legal epistemologies, particularly those that reinforce rigid distinctions between body and mind, emotion and reason, have been variously exported and imposed in a number of different colonial contexts, including Canada.

Throughout $R$. v. Kapp these dualisms are mobilized in ways that racialize and gender both the litigants and the beneficiaries of the government programs at issue in the case. This analysis will therefore answer Kimberlé Crenshaw and Angela Harris's calls for a critical examination of the gender dynamics at work in cases that are framed by race alone ${ }^{17}$ in addition to addressing one of the key insights in the sociological literature on gender and the feminist, trans and queer scholarship on performativity and female masculinities. Namely, that one need not identify as a cis-gendered or trans man to be masculine, perform masculinity, or reify and value only the stereotypically masculine side of the dualism at the expense of the other. ${ }^{18}$ All of this theory taken together, however, is limited. None of these critical approaches to understanding language or the law explicitly addresses settler colonialism.

Following Bonita Lawrence and Enakshi Dua's calls for feminist antiracist scholarship to take decolonization seriously, this article will address this limitation in order to unsettle the settler narratives that are central to the strategies of argumentation and justification that appear in the defense witness testimony and the claims of the accused. ${ }^{19}$ I have already argued elsewhere that Corbiere's formalistic approach to the grounds of discrimination tethers judicial interpretation to the logics of colonial modernity. ${ }^{20}$ In conjunction with this grounds approach, the defense witnesses and the judges in $R$. v. Kapp also relied on a range of different discursive strategies that continue to serve both internal and external

16 Carol Smart, Feminism and the Power of Law (London: Routledge, 1989); Margaret Thornton, "Feminist Jurisprudence: Illusion of Reality?" (1986) 3 Australian JL \& Society 5; Ngaire Naffine, Law and the Sexes: Explorations in Feminist Jurisprudence (Sydney: Allen \& Unwin, 1990).

17 Kimberlé Crenshaw, "Demarginalizing the Intersection of Race and Sex: A Black Feminist Critique of Antidiscrimination Doctrine, Feminist Theory and Anti-Racist Politics” (1989) U Chicago Legal F 139; Kimberlé Crenshaw, "Mapping the Margins: Intersectionality, Identity Politics and Violence Against Women of Color" (1991) 43 Stan L Rev 1241; Angela P Harris, "Gender, Violence Race and Criminal Justice,” (2000) 52 Stan L Rev 777.

18 Judith Butler, Gender Trouble (New York: Routledge, 1990) [Butler, Gender Trouble]; Judith Butler, Undoing Gender (New York: Routledge, 2004) [Butler, Undoing Gender]; RW Connell, Masculinities, $2^{\text {nd }}$ ed (Cambridge: Polity, 2005)[Connell, Masculinities]; Judith Halberstam, Female Masculinty (Durham: Duke University Press, 1998); JW Messerschmidt, Flesh and Blood: Adolescent Gender Diversity and Violence (Lanham, MD: Rowman \& Littlefield, 2004); Gillian Ranson, "No Longer "One of the Boys": Negotiations with Motherhood, as Prospect or Reality, Among Women in Engineering" (2005) 42:2 Can Rev Sociology 145; Candace West \& Don Zimmerman, "Doing Gender" (1987) 1:2 Gender \& Society 125.

19 Bonita Lawrence \& Ena Dua, "Decolonising Antiracism" (2005) 32:4 Social Justice, 120; Eve Tuck \& Wayne Yang, "Decolonization is not a Metaphor" (2012) 1:1 Decolonization, Indigeneity, Education \& Society, online: $<$ http://decolonization.org/index.php/des/article/view/18630>

20 Caroline Hodes, "Intersectionality in the Canadian Courts: In Search of a Decolonial Politics of Possibility" (2017) 38:1 Atlantis 72 [Hodes, "Intersectionality"]. 
forms of settler colonialism and that often reappear in other institutional and social contexts. ${ }^{21}$ As a result, while masculinities analysis can and does deepen an intersectional understanding of the multiple meanings of inequality, hierarchy and subordination in cases like R. v. Kapp, it is also important to begin unsettling the investment in a gendered and racialized settler futurity that contemporary equality claims often represent. Doing so pushes feminist anti-racist legal scholarship, and socio-legal studies more broadly, to examine the epistemological foundations of both the discursive and structural impediments to reconciliation and access to justice in Canadian anti-discrimination law.

\section{UNSETTLING SETTLER FUTURITY}

Revisiting R. v. Kapp is timely given the recent recommendations of Canada's Truth and Reconciliation Commission [TRC]. In 2015, the TRC released ninety-four calls to action outlining concrete ways that Canadian individuals, governments and institutions can work to redress the legacies of residential schools. ${ }^{22}$ Built on the Federal Government of Canada's statement of reconciliation that was released in the same year that the commercial fishers initiated their protest fishery (1998), the TRC was tasked with the responsibility of gathering and recording the diverse stories of former students, staff, administrators, church and government officials. Based on its findings, the TRC was also responsible for developing a series of recommendations to the federal, provincial and territorial governments.

The ninety-four calls to action are the TRC's recommendations and many Canadian institutions and educators are currently grappling with developing strategies to implement them. Two of them specifically call for "the repudiation of concepts used to justify European sovereignty over Indigenous lands and Peoples such as the Doctrine of Discovery and terra nullius" and to "reform those laws, government policies, and litigation strategies that rely on such concepts". ${ }^{23}$ Drawing on the work of Aileen MoretonRobinson who traces the colonial systems of knowledge production that held sway prior to the landmark Mabo decision that repudiated the concept of terra nullius in Australia, Audra Simpson describes the multiple ways that "categorical forms of recognition and mis-recognition are indebted to deep philosophical histories of seeing and knowing". ${ }^{24}$ When these categorical forms of (mis) recognition are applied in sites of institutional power like courtrooms and classrooms, they enable "disproportionately empowered political forms (such as 'Empire' or particular nation-states such as the United States, Canada and Australia) to come into being in a very short time". ${ }^{25}$

In the Canadian context, colonial knowledges are often reproduced as common sense or reified as truth, reality and/or fact through text, talk and political action. Discourse thereby becomes the means through which struggles over identity, belonging and entitlement take place. Although decided before the TRC issued its final report, the legal construction of the fishery in the common law combined with the discursive

21 Tuck \& Yang, supra note 19.

22 Canada, Truth and Reconciliation Commission of Canada, Truth and Reconciliation Commission of Canada: Calls to Action. (Winnipeg: Truth and Reconciliation Commission of Canada, 2015), online: $<$ http://www.trc.ca/websites/trcinstitution/index.php?p=3>; P Regan, Unsettling the Settler Within: Indian Residential Schools, Truth Telling, and Reconciliation in Canada (Vancouver: University of British Columbia Press, 2010).

23 Ibid.

24 Audra Simpson, “On Ethnographic Refusal: Indigeneity, 'Voice' and Colonial Citizenship” (2007) 9 Junctures 67 at 69.

25 Ibid. 
strategies that appear in the witness testimony and the judicial decisions in $R$. v. Kapp provide insight into how colonial knowledge is both reified in discourse and manifested materially through law.

Eve Tuck and Wayne Yang define colonialism in terms of both external and internal processes. External colonialism is that which extracts and expropriates "fragments of Indigenous worlds, animals, plants and human beings" in order to feed the wealth and appetites of settler societies. ${ }^{26}$ The commercial fishing industry can be seen to play this extractive role through the harvesting and sale of fish. They define internal colonialism as "the biopolitical and geopolitical management of people, land, flora and fauna within the domestic borders of the imperial nation". ${ }^{27}$ In the context of the salmon fisheries, the state can be seen to play this role through provincial and federal management of the fisheries resource. This includes the determination of fines and criminal sanctions for things like poaching and fishing at a prohibited time. It also includes the allocation of different kinds of geographically specific licenses that determine who can fish at what times and which types of gear can be used in addition to measures designed to regulate how many fish can be taken and whether or not the fish can be sold for commercial purposes. Many of these regulations are put in place in the interests of conservation in order to preserve the resource for long-term economic gain.

The PSPs that were challenged in $R$. v. Kapp were part of a larger strategy aimed at redressing the longterm economic effects of colonial laws and policies on Indigenous communities. The PSP that was at issue in this case was designed as part of the federal government of Canada's Aboriginal Fisheries Strategy [AFS]. In 1992, the Department of Fisheries and Oceans Canada adopted the AFS in response to the 1990 Supreme Court ruling in the R. v. Sparrow case. ${ }^{28}$ In 1984 Ronald Sparrow, a member of the Musqueam Band, was arrested for fishing in contravention of his fishing license. He was using a net that was longer than it should have been under his license to fish for food. Both the BC Provincial Court and the BC County Court upheld his conviction. He later appealed, won his appeal, and the Supreme Court of Canada ruled that the Musqueam Band's right to fish had not been extinguished. The Court also affirmed the constitutional rights of Indigenous Peoples to fish for food, social and ceremonial purposes, and laid out the test for whether or not a governmental infringement of Aboriginal rights was justified. The Court expressed in Sparrow and later affirmed in both Delgamuukw and Haida Nation, a distinct preference for negotiation over litigation. ${ }^{29}$ The AFS is part of a government led strategy to attempt to resolve Aboriginal rights disputes before they go to court. The PSPs were part of an overall policy attempt to recognize and honour Aboriginal rights through negotiated agreements more broadly. Despite these laudable goals, commercial fishers have protested PSPs since their inception.

A number of different cases had already been initiated prior to the protest that led to $R$. $v$. Kapp. John Cummins, a federal member of Parliament, was, like the fishers in Kapp, charged with fishing at a prohibited time. The BC Provincial Court ruled that if the fisheries were closed, they should have been closed to everyone and declared Aboriginal fishing licenses to be unlawful. ${ }^{30}$ In $R$. v. Huovinen the

Tuck \& Yang, supra note 19 at 5.

Ibid at 4.

$28 \quad R$ v Sparrow [1990] 1 SCR 1075.

29 Ibid; Delgamuukw v British Columbia [1997] 3 SCR 1010; Haida Nation v British Columbia (Minister of Forests) [2004] 3 SCR 511.

30 See the reasons of Judge Thomas $R v$ Cummins, (26 January 1998), Surrey Registry No 93472-01 [unreported]; in $R v$ Cummins [1998] BCJ No 125 (BCPC). 
protesters were also arrested for fishing during a closed time. In contrast to the fishers in R. v. Kapp, they alleged that allowing certain Indigenous communities to fish to the exclusion of the rest of the commercial fleet was an abuse of process rather than race discrimination under the Charter. Judge Thomas, the same judge who ruled that Aboriginal fishing licenses were unlawful in John Cummins' case, stayed the proceedings against them. ${ }^{31}$ The BC Supreme Court allowed an appeal where the stay of proceedings was lifted and the licenses were eventually upheld as lawful. ${ }^{32}$ In a third case decided weeks before Judge Kitchen's 2003 ruling in R. v. Kapp, the protest fishers alleged that the fisheries should have remained open to everyone. In $R$. v. Anderson, BC Provincial Court Judge Saunderson decided that the licenses issued under PSPs allowed for the creation of "race-based" fisheries and claimed that the programs were examples of "misguided political correctness". ${ }^{33}$ He justified his conclusions by claiming that the actions of the protest fishers constituted a form of "ccivil disobedience' in the face of state action that drew distinctions "based on race"."34

All of these cases were adjudicated using administrative law doctrines. As a result, with the exception of Huovinen in relation to the non-Charter issues that were raised at trial, none of these decisions were binding on the judges in R.v. Kapp. ${ }^{35}$ Some of the outcomes in these cases were pending at the time of the initial trial and because many of the administrative challenges did not succeed in favour of other commercial fishers on appeal, $R$. v. Kapp moved forward as primarily a race discrimination claim under s. 15 of the Charter. Together, these other cases provide context for both the testimony of the commercial fishers who acted as witnesses in this case and the language that the Provincial Court Judge used to establish his facts and justify his 2003 decision in R. v. Kapp.

Central to all of these claims is the legal construction of the fisheries as common property resources characterized by a formal equality right of public access. In $R$. v. Kapp, this was foundational to not only the commercial fishers' claim to the fish but also to their understanding of discrimination. Their legal counsel likened the fishery to an employer and argued that this was a case of workplace discrimination. ${ }^{36}$ The common law provided the structural framework for the Provincial Court Judge to bolster the claims of the accused and the defense witnesses. It also provided a legal foundation for the Supreme Court of Canada to maintain that the fishery was equivalent to a workplace at the same time as they respected the principles of substantive equality that are central to Charter equality rights analysis.

Judge Kitchen's re-articulation of the commons was pieced together through English law, principally the Magna Carta, and US and Canadian colonial case law. It became foundational to the performance of masculinity and the strategies of argumentation and justification that the defense witnesses relied on in their testimony. It was also clearly reflected in the submissions of the accused, the briefs of industry representatives and intervenor groups, and in the decisions of the Supreme Court and appellate court

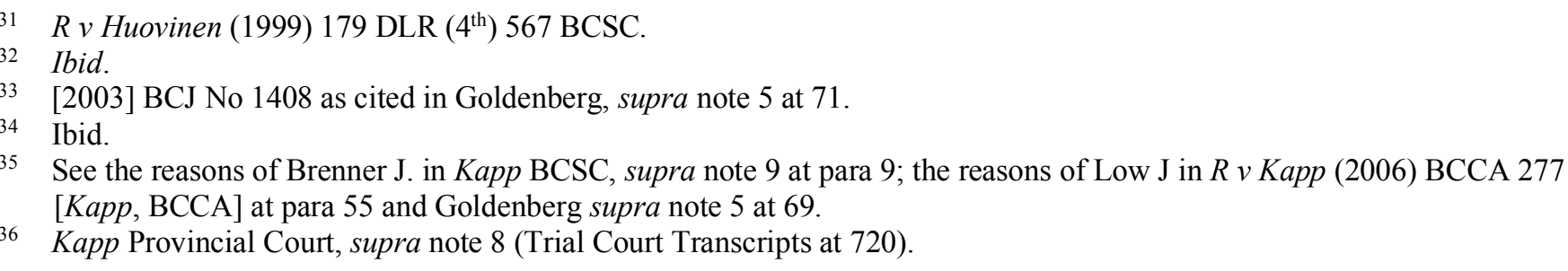


judges. ${ }^{37}$ In their final ruling, this framing of the fishery enabled the Supreme Court to create an affirmative action program out of the PSPs and the Aboriginal Fisheries Strategy more broadly. This strategy likened these programs, which were intended as interim measures on the way to self-governance and contemporary treaty negotiations, to federal employment equity programs, the beneficiaries of which became analogous to federal employees. This reframing of the co-management regime through s. 15(2) of the Charter erased the Indigenous contribution to these programs. In doing so, self-governance and co-management were eclipsed in favour of inclusion into the pre-existing colonial legal framework for the commons. ${ }^{38}$ Whatever the final conclusions of any of the judges, all articulations of the fishery as a regulated common property resource in this case are produced through restatements of distinctly Lockean discourses on property.

In the Second Treatise of Government John Locke developed theories of labour, property and spoilage that distinguish natural rights that existed prior to the state, its sovereignty or the existence of civil society. In his origin story, Locke creates a state of nature whereby "every man has property in his own person", property in "the labour of his own body" and property rights vested in "whatsoever [he] removes out of the state of nature" through "the work of his hands." ${ }^{39}$ In this formulation, "God, who has given the world to men in common, has also given them reason to make use of it to the best advantage of life and convenience." ${ }^{40}$ God is therefore the first governor of humankind and in the Provincial Court Judge's restatement of the Lockean narrative, the state has assumed the role that Locke assigns to God. Indeed, as one of the defense witnesses testified: “...it states in the Canadian Constitution, and I heartily believe that it's right in doing so, that we are all created equal in the eyes of the Lord." 41

In this formulation, the salmon are understood to belong to whoever catches them first and the only justifiable regulations are those crafted by the state to ensure the longevity of the resource for public consumption. In her account of the Lockean discourse that governs environmental economics, Rebecca Judge points out that when the state is substituted for "Locke's God" the state acquires "title to all yetunclaimed, yet-discovered, and yet-invented assets." ${ }^{42}$ Locke writes in the Second Treatise: God gave the earth to "the industrious and rational." ${ }^{43}$ In his account of the commons, the capacity for reason is what endows humans with the ability to figure out that appropriating goods from the common property resource is only worthwhile as long as the benefits accrued from those goods exceed the costs of extraction. In addition, although humans have a natural right to appropriate goods through their labour, because God created the commons for everyone, respecting restrictions on this right of extraction is paramount.

37 Kapp BCSC, supra note 9 at paras 13 and 46; Kapp, BCCA, supra note 35 at para 18 as per Low J; Kapp SC, supra note 3 at paras. 68,68 and 112 as per Bastarache J

38 See Sarah E Hamill, "The Public Right to Fish and the Triumph of Colonial Dispossession in Ireland and Canada," (2017) 50 UBC L Rev 53 for a window into the multiple ways that the public right to fish has been invoked in service of colonial dispossession.

39 John Locke, Second Treatise on Government, CB MacPherson, ed, (Cambridge MA: Hackett Publishing, 1980) at para. 27.

$40 \quad$ Ibid at paras 26-31.

$41 \quad$ Ibid at para. 121.

42 Rebecca Judge, "Restoring the Commons: Toward a New Interpretation of Locke's Theory of Property" (2002) 78:3 Land Economics 331 at 336.

$43 \quad$ Supra note 39 at para 34. 
Therefore, regulations are required to prevent human beings from taking more than they need lest the fruit of the commons be wasted or allowed to spoil. For Locke, if a person were to collect more than they could consume and allowed goods to spoil, this would not be reasonable, industrious or in keeping with the wishes of God. Similarly, hoarding land with the inability to cultivate it or hoarding resources in a way that leads to excess consumption at the expense of others - precisely what the commercial fishers were alleging was happening as a result of the PSPs - would be equally unacceptable. Although Judge overlooks this in her review, the preservation of this idealized Lockean commons is also dependent on the ability of a gendered and racialized civil society to ensure its just use. ${ }^{44}$

The legal framework for common property resources that appears in the Provincial Court Judge's ruling restates this Lockean discourse. It becomes the legal foundation that enables the judge to recontextualize the defense witness testimony in terms of the formal equality right of public access. This mobilization of the commons, however, had the effect of racializing and feminizing the beneficiaries of the PSPs in ways that bolstered the commercial fishers' claim to not only the fisheries, but also to the kind of masculinity that places Lockean forms of justice, reason, just war and industry as central to the exercise of citizenship.

Beginning with Attorney General for BC v. Attorney General of Canada, a case decided in 1914, Judge Kitchen framed the fishery as follows:

[I]t has been unquestioned law that since the Magna Carta no new exclusive fishery could be created by Royal grant in tidal waters, and that no public right of fishing in such waters, then existing, can be taken away, without competent legislation...their Lordships entertain no doubt that this is part of the law in British Columbia. ${ }^{45}$

He also cited an early Twentieth Century US case, Lewis v. State, where the common law right was defined as a right "which one individual of the whole community is entitled to enjoy as much as another, [that] cannot be made by law the exclusive privilege of the people of a certain class or section upon terms and conditions that do not apply to the whole people." ${ }^{36}$ With regard to the regulatory power of the state at both the federal and provincial levels, Judge Kitchen cited Chief Justice McLachlin in Ward v. Canada who articulated:

[The] preponderance of authority suggests that the fisheries power is not confined to conservation, nor to pre-sale activities, but extends more broadly to maintenance and preservation of the fishery as a whole, including its economic value. In The Queen v. Robertson (1882) 6 S.C.R. 52, Ritchie C.J. described the fisheries power as extending 'to subjects affecting the fisheries generally, tending to their regulation, protection and preservation'. Accordingly, Parliament's power extended to 'all such general laws as enure as well as to the benefit of the owners of the fisheries as to the public at large, who are interested in the fisheries as a source of national or provincial wealth... ${ }^{37}$

44 See Carole Pateman, The Sexual Contract (Bloomington: Stanford University Press, 1988).

45 Kapp Provincial Court, supra note 8 at para 7.

46 Ibid.

$47 \quad$ Ibid at para. 24. 
The legal construction of the commons restates the colonial doctrine of terra nullius through a reliance on English law, Canadian colonial law and US cases that further settler occupation. Claiming land and, in this case the fisheries, for the Canadian commons through the assertion of "consensus as the rule of the commons, erases existing, prior and future Native" rights to the fisheries and the regulatory practices that pre-existed state control of the resource. ${ }^{48}$ As a result, this legally constructed commons plays a similar role with regard to the fisheries that planting a flag, placing a foot or reading out a declaration on what was considered to be empty or unoccupied land historically played in claiming that land by the representatives of colonizing powers. ${ }^{49}$ Nevertheless, Judge Kitchen used this legal framework to highlight the feelings of injustice and exclusion that are described in the witness testimony. His conclusions and the testimony reveal the centrality of both race and gender to the collective understanding the fishery, the meaning of discrimination and the labour that creates property out of the fruits of the commons in this case.

Judge Kitchen's recontextualization of Robert McKamey's testimony is illustrative. In his final ruling, Judge Kitchen introduces McKamey by invoking the "Native lady" that McKamey's great, great grandfather had married in conjunction with excerpts of his testimony where he outlines his understanding of the public right of access to the fishery. ${ }^{50}$ Following Vine Deloria Jr., Tuck and Yang have theorized the invocation of Native grandmothers as a key settler move to innocence. ${ }^{51}$ Settler moves to innocence are grounded in discursive strategies such as the construction of in-groups or out-groups and practices of nomination that include self and other identification. This is often part of a process that they refer to as settler nativism. Settler Nativism is rooted in attempts to generate absolution through the deflection of settler identities in order to justify the continued occupation of un-ceded land and the ongoing ability to benefit from the privileges accrued as a result of colonization. Vine Deloria Jr. has theorized the gendered nature of settler nativism through what he calls "the Indian grandmother complex." ${ }^{, 2}$ Deloria Jr. describes multiple reasons why a grandmother might have more appeal than a male relative for settlers, indicating that "[a] male ancestor has too much of the aura of the savage warrior, the unknown primitive, the instinctive animal to make him a respectable member of the family tree". ${ }^{53}$

Historical legal records reveal that at times, early settlers had both Indigenous and non-Indigenous wives, sometimes concurrently, at other times consecutively, and on occasion, non-Indigenous men fathered children with both. ${ }^{54}$ But because the Provincial Court Judge invoked a biological conception of race in his reasons through the accused's perception that to participate in the PSP one was required to have a bloodline connection to the First Nations who negotiated the terms of the program, it can be inferred that her inclusion in the testimony and the judge's ruling was meant to lead to the conclusion that McKamey's male relatives are her descendants.

48 Tuck \& Yang, supra note 19 at 28.

49 See John Borrows, "The Durability of Terra Nullius: Tsilhqot'in Nation v. British Columbia” (2015) 48:3 UBC L Rev 701.

50 Kapp Provincial Court, supra note 8 at para 88.

51 Vine Deloria Jr, Custer Died for Your Sins: An Indian Manifesto (Norman, OK: University of Oklahoma Press, 1988) at 2-4, cited in Tuck \& Yang, supra note 19 at 11.

52 Ibid.

53 Ibid.

54 Connolly v Woolrich et al. (1867), 17 R.J.R.Q. 75 (Superior Court of Québec). 
Even though none of the defense witnesses used the language of bloodlines in the excerpts of their testimony that the judge cited in his decision, strategies like this one lead to the inference that Indigeneity constitutes a biologically inherited race. In conjunction with the invocation of his great, great grandmother, McKamey also claimed that before the PSP came along: "[e]veryone was entitled to fish wherever you wanted when fishing was open, and so we fished...You fish where you know how to fish and you know how to fish there because that's where your dad fished and that's where your dad's dad fished". ${ }^{55}$ While McKamey's proprietary interests in the fishery are secured through the Patrilineal line beginning with a male settler, his Native great, great grandmother endows him with the absolution garnered as a result of his distant biological kinship ties.

The settler nativism present in this testimony is further reinforced in the judge's brief introduction of each subsequent witness. These introductions often include details that draw on intergenerational, marital and biological connections and, at times, they invoke group affiliations, educational levels, the gradual acquisition of wealth and citizenship status. Together, these discursive strategies yield two interdependent conclusions. The first is aimed at showing that the twenty-four-hour restriction undermines the formal equality right of public access to the fisheries outlined in the common law. The second absolves the claimant group of their responsibility for both fishing at a prohibited time and accounting for the unearned privileges that they possess as a result of engaging in ongoing colonial practice. Underlying these discursive strategies is a sense of entitlement to the fishery. Many of the defense witnesses testified to their Native heritage, sometimes together with a claim of Canadian citizenship while others made reference to the formal equality right of public access as central to their ability to exercise that citizenship.

In a number of cases the claims made by these witnesses mirror the right of public access laid out in the legal construction of the fishery. The principle of formal equality, whereby likes should be treated alike, underpins their collective understanding of fairness, exclusion and discrimination. The following excerpts of testimony are illustrative. Kim Nguyen invoked the right outlined in Lewis v. State when she claimed:

When I became a Canadian, I remember when I swear, I obey the law. I have freedom to speak. Equal rights, and everything. I thought that's the - I would have the right to say now. We wants one fishery do for everybody the same and equal. They can have it; we can have it, too... ${ }^{56}$

Michael Forrest invoked the right outlined in $A G$ for $B C$ when he claimed:

There should be one commercial fishery. One manageable commercial fishery instead of two.... The fisheries that were in your control were the commercial fisheries. The fisheries that weren't in your control were the Aboriginal ones. ... The fishery we could open and close was the commercial fishery, as I've said. We couldn't open and close the Aboriginal one. ${ }^{57}$

55 Kapp Provincial Court, supra note 8 at paras 91 and 92.

56 Kapp, Provincial Court, supra note 8 at para 116.

57 Kapp Provincial Court, supra note 8 at para 108. 
Debra Logan also invoked the right as outlined in Lewis v. State:

I think probably my most fundamental objection to [the pilot sales program] is that it states in the Canadian Constitution, and I heartily believe that it's right in doing so, that we are all created equal in the eyes of the Lord. And I just don't feel that differentiating in terms of privilege in this country is acceptable. I don't think it's fair to Canadians. I think it's even less fair to Indians...

... [I] sn't it sad that within our country, we're ... creating a race with different privileges and rights. ${ }^{58}$

Donna Sonnenberg invoked the right but made an allowance for food fisheries that is very much in keeping with Locke's repudiation of excess consumption at the expense of others:

I don't understand why the Indians should have their own special commercial fishery. They have their food fishery that I have no problem with whatsoever, providing the food goes to a food fishery. ... I don't see us having our own special fishery at certain times with no Indians in them... 59

Similarly, Stewart McDonald invoked the right by characterizing food fisheries as means to launder the excess fish taken through the PSP:

...it offered a way to launder food fish in great quantities that was difficult before pilot sales because if a Native went out food fishing and he had too many fish, it was too difficult to sell them. [But after pilot sales] the Native people would take their fish to cold storage and freeze them and then when a pilot sales fishery came along, that was an opportunity to launder them all through what they believed was a legitimate pilot sales fishery... People had the opportunity to fish for days on end in the food fishing, when the food fishing was open and take the fish to cold storage and sell it to brokers and say it was caught in the pilot sales. ${ }^{60}$

Accusations and fears of excess consumption at the expense of others through practices of fish laundering were common to both the defense and the Crown's submissions is this case. Evidence of poaching was marshalled to bolster the discrimination claim as exemplified in McDonald's testimony, but it was also used to argue for the constitutionality of the program. Even though evidence was produced at trial suggesting that poaching was common practice across commercial fisheries irrespective of community membership, Fisheries and Oceans Minister John Crosbie's 1993 testimony to the Standing Committee on Forestry and Fisheries was used at all levels of court to advance the argument that the PSPs would solve the poaching problem thereby implying that Indigenous fishers were the only ones doing it. In addition to evidence about the need for conservation, Crosbie claimed:

$58 \quad$ Ibid at para 121.

$59 \quad$ Ibid at para 97.

$60 \quad$ Ibid at para 99. 
We're doing this because we think it's the best public policy, because we know for years and years in British Columbia and elsewhere there's been poaching of fish. We call it poaching. The Aboriginals say they have a right to do it. ${ }^{61}$

Crosbie's account was subsequently reiterated at the Supreme Court in their final ruling as the requisite opening for a discussion on the scope and purpose of s. 15(2) of the Charter. While the majority pulled evidence of poaching from the Gardner Pinfold and Pearse reports, Justice Bastarache's ruling cited Crosbie directly in his application of s. 25 of the Charter. ${ }^{62}$

Judge Kitchen's restatement of the Lockean commons and its regulatory regime pieced together through the defense witness testimony and the caselaw endows the state with the ability to appropriate resources, land and goods and to govern. The ability to govern through regulation, however, is only justifiable provided that the state does not abuse this power. In the discursive construction of the Lockean commons, the public right of access is passed down through the patrilineal line and must remain uncontaminated by race-based measures that enable some to get their catch "the easy way." ${ }^{63}$ In this discursive context, if the government regulations are perceived to be unfair, commercial fishers are entitled to engage in forms of civil disobedience in order to protect the commons by laying proprietary claims to gender-based forms of citizenship that entitle them to the fish. This type of civil disobedience is very much in keeping with the Lockean formulation of just war/revolution, or banding together to overthrow absolute power by force.

For Locke power is something steeped in relations of domination, self-defense, acquisition and liberation. The threat of domination or theft justifies the creation of a civil society that is the domain of rational men. Men are rational to the extent that they can abstract to the idea of God, or in Judge Kitchen and Rebecca Judge's restatements of the Lockean commons, the state, who instructs them to mix their labour with land and goods in order to have property. And finally, these reasonable men enter into a compact that will liberate them from the state of nature through the ability to defend themselves and their property from absolute power or, in this case, unjust state imposed regulations ${ }^{64}{ }^{6}$ In this case both the commercial fishers and the trial court judge framed the protest as a civil defense of the commons. On appeal, however, "civil disobedience" like "protest fishery" were both identified as terms that are "unknown to the law" in Canada ${ }^{65}$ Despite their best attempts at holding one government program responsible for all of the hostility on the water, there were also a number of other constraints in place both prior to and at the time of the protest fishery that would have also impacted their ability to fish.

$61 \quad$ Kapp SC, supra note 3 at para 47.

62 Canada, Commission on Pacific Fisheries Policy, Turning the Tide: A New Policy for Canada's Pacific Fisheries: Final Report (Vancouver: The Commission, 1982) (Pearse Report); Canada, Department of Fisheries and Oceans, An Evaluation of the Pilot Sale Arrangement of Aboriginal Fisheries Strategy (AFS) (Halifax: Gardner Pinfold Consulting Economists, 1994); Kapp SC, supra note 3 at para 72 as per Bastarache J.

64 Locke, supra note 39 and Judge, supra note 42.

65 Kapp, BCCA, supra note 35 at para 92 as per Low J. 
Since 1969, the government of Canada has been engaging in various different kinds of buyback strategies to reduce the size of the commercial salmon fishing fleet. ${ }^{66}$ In the 1990's there was a specific push to reduce the number of salmon licenses and the number of vessels. In 1998, compensation was paid to license holders who chose not to fish. Four hundred million dollars was made available to support an enhanced program to rehabilitate the salmon, restructure the fishery and provide alternatives through retraining programs for fishers who had to leave the commercial fishing industry or provide loans for those who had to adjust their methods of fishing to meet the new regulatory regime. ${ }^{67}$ In addition, as noted by Judge Kitchen in his ruling, the government bought back some of these licenses at market value and made them available to Indigenous fishers. ${ }^{68}$ At the time of the protest, Debra Logan, one of the defense witnesses who was also the executive director of the B.C. Beam Trawlers' Association for shrimp trawlers, had retired her license under the Aboriginal Fishing Strategy license retirement program. ${ }^{69}$

In his review of the buyback programs from 1996 to 1998, Ben Muse evaluates different management strategies pointing to the limits of the common property framework most notably in terms of overspending and overfishing. ${ }^{70}$ Contrary to the Lockean imperative, in a common property fishery, fishers tend to overinvest in gear and vessels in order to win the race for the salmon. This competition often leads to the overharvesting of spawning stocks that eventually causes lower annual salmon returns and less fish for future harvests.

At the time of the protest, market prices for salmon had already been severely impacted in the early to mid-1990's by Japan's recurrent recession and financial crisis. Japan's salmon market played a crucial role in buoying BC Pacific salmon prices. In addition, the advent of farmed salmon created a much deeper and more permanent problem in terms of demand. Large quantities of farmed salmon from Norway and Chile competed heavily with the $\mathrm{BC}$ salmon producers. ${ }^{71}$ And finally, the fisheries were eventually closed two years prior to the 2008 Supreme Court decision due to the disappearance of the salmon. This prompted the federal government to hold a commission of inquiry into the decline of the Sockeye (hereinafter the Cohen Commission). Among the many submissions that were reviewed, Kristi Miller had published an inconclusive study in the journal Science pointing to a form of leukemia that was transmittable between the fish. ${ }^{72}$ The Cohen Commission's final report reveals a number of stressors in

66 Canada, Department of Fisheries and Oceans, Policy and Practice Report, Commercial Salmon Fishing: Licensing and Related Issues (Ottawa: Queen's Printer, 2010); Quentin R Grafton \& Harry W Nelson, "The Effects of Buyback Programs in the British Columbia Salmon Fishery," paper prepared for the International Workshop on Fishing Vessel and License Buyback Programs, 22-24 March 2004, Online: Institute of the Americas <

file://Users/carolinehodes/Downloads/grafton2.PDF>; Theodore Groves Theodore \& Dale Squires, "Lessons from Fisheries Buybacks" in Rita Curtis \& Dale Squires, eds, Fisheries Buybacks (Wiley Online: Blackwell Publishing, 2007) 15, online: <http://onlinelibrary.wiley.com/book/10.1002/9780470277836>; Ben Muse, "Fleet Reduction in British Columbia's Commercial Salmon Fisheries: 1996-1998” (1999), online: Alaska Commercial Fisheries Entry Commission $<$ https://www.cfec.state.ak.us/RESEARCH/buyback/BC_BB_2.PDF>

67 Ibid.

68 Kapp Provincial Court, supra note 8 at para 160.

69 Ibid at para. 117.

70 Muse, supra note 66.

71 Ibid at 5.

72 Kristi KM et al, “Genomic signatures predict migration and spawning failure in wild Canadian salmon,” (2001) 331:6014 Science 214. 
both fresh and marine water environments ranging from climate change and contaminants to predation and disease that together led to the decline of the Sockeye in the region. ${ }^{73}$ The stresses on the fish, these witnesses and the accused, therefore, came from multiple directions and among the least impactful were the PSPs at issue in this case.

The discursive construction of the Lockean commons, however, was not the only way that formal equality was invoked through gendered processes of racialization. This combination of conservation issues, market crises and revised management techniques galvanized into a crisis of masculinity. Throughout their testimony, the commercial fishers engaged in practices of self and other identification that relied on discursive strategies of nomination that emasculated the beneficiaries of the pilot sales program. They also had feelings. Combined with their claims to the formal equality right of public access outlined above, this evidence did not mix well with either the legal framework for substantive equality under s. 15 of the Charter or the androcentric dualisms that lie at the heart of Canadian legal reasoning.

\section{FEELINGS, CITIZENSHIP AND DIFFERENCE IN THE COLONIAL CONTEST}

At the Supreme Court of British Columbia, Justice Brenner turned Judge Kitchen's analysis around. He reintroduced relative disadvantage into the grounds inquiry and concluded that the commercial fishers in this case "are part of a more advantaged group... [who arguably]...enjoy an even greater advantage than the rest of Canadian society in that they are among the very few who are able to obtain a commercial fishing license". ${ }^{74}$ But, in order to do this, he had to follow the androcentric reasonable person standard at the heart of the Law test.

The third prong of the Law test is accompanied by a directive that was first laid out in Egan by Justice Claire L'Heureux-Dubé and was subsequently reiterated in Law and later, Corbiere. ${ }^{75}$ This directive stipulates that alleged breaches of dignity based on the grounds of discrimination should be assessed from the perspective of someone simultaneously endowed with the features that Smart and Thornton draw attention to in their analyses of idealized forms of masculinity in law and the immutable characteristics of the claimant: "the reasonable person, dispassionate and fully apprised of the circumstances, possessed of similar attributes to, and under similar circumstances as, the claimant". ${ }^{76}$ Applying this directive to his interpretation of the Law test, Justice Brenner concluded:

$[\ldots]$ in the court below the claim was not assessed from the perspective of a reasonable, fully informed and dispassionate person. Rather the claim was assessed from the perspective of a number of defense witnesses. In fact, their perception was accorded more weight than reality. ${ }^{77}$

73 Canada, Commission of Inquiry into the Decline of the Sockeye Salmon in the Fraser River, The Uncertain Future of the Fraser River Sockeye, vol.3 (Ottawa: Public Works and Government Services Canada, 2012) [Cohen Commission] at 3.

74 Kapp BCSC, supra note 9 at para 98.

75 Egan v Canada [1995] 2 SCR 513 [Egan]; Law, supra note 1; Corbiere, supra note 2.

76 Egan, supra note 72 at para 56; Law, supra note 1 at 533; Corbiere, supra note 2 at para 60.

77 Kapp BCSC, supra note 9 at para 75. 
Justice Brenner's claim that Judge Kitchen accorded the perceptions of the defense witnesses "more weight than reality" brings up the variety of ways that having feelings is a problem in Canadian antidiscrimination law. The testimony reveals that the perceptions of these witnesses were rooted in their feelings of exclusion and marginalization. These feelings were largely predicated on the belief that they were being denied the formal equality right of public access that is central to Judge Kitchen's common law articulation of the fisheries. Beginning with Justice Brenner's decision, perceptions, and by extension the feelings that gave rise to them, were included among the problems that needed to be solved in all of the appellate court decisions.

At the BC Court of Appeal, both Justice Low's and Justice Mackenzie's reasons supported Justice Brenner's conclusions. They articulated that not only did these perceptions erroneously find their way into evidence, but that Judge Kitchen had relied on them too heavily, thereby failing "to give adequate weight to the facts viewed objectively". ${ }^{78}$ As can be seen in Mackenzie J.'s articulation of the problem with the witness testimony, it was the Law test that created the unique forum within which claimants were expected to have feelings only to have them scrutinized by a reasonable, dispassionate person who is expected to share everything in common with them, including what would later become their immutable characteristics in Corbiere.

These feelings are what ultimately undermined the credibility of the defense witnesses in $R$. v. Kapp. In keeping with Smart and Thornton's insights regarding the phallogocentrism of law, Naffine articulates that "blind justice" or the official story that law tells itself about itself, means the ability "to think abstractly and objectively". ${ }^{79}$ Phallogocentrism elides phallocentricity, or what Carol Smart refers to as "the masculine heterosexual imperative" with logocentrism, the idea that linguistic signs are distinct from the reality that they are used to describe. Smart's assessment that "knowledge is not neutral but produced under conditions of patriarchy" is a provocation to the story that law and some linguistic analyses tell themselves about themselves. ${ }^{80}$ The divergent discursive representations of reality that occur in the judicial decisions and the witness testimony that informs most court cases are not, in fact, distinct from the reality they purport to describe. They are, rather, constitutive of that reality. In $R$. v. Kapp, these discursive representations manifested materially through the formal equality right of public access outlined in the common law and culminated in a protest fishery that eventually led to a decade of litigation. All of the divergent accounts in this case provide the contextual foundation for the discursive contest over whose version of reality will win. In this case, gender and race shape every aspect of that reality from how the common property resource and the occupation of fishing are understood to the discipline of law itself.

Smart argues that law and masculinity are congruent in the sense that the normative performance of one side of what Thornton refers to as "a series of sexualised, hierarchised dualisms" is idealized and reified. The disproportionate value that is placed on the qualities of "thought, rationality, reason, culture, power, objectivity and abstract and principled activity" in law is dependent on the devaluation of what are considered to be their opposites, i.e. corporeality, passion, emotion, nature, weakness, subjectivity and

78 Kapp, BCCA, supra note 35 at para 51 as per Low J and para 109 as per Mackenzie J.

79 Naffine, supra note 16 at 58.

80 Smart, supra note 16 at 86. 
embodied and particular experience. ${ }^{81}$ As in Thornton's assessment, Naffine claims “...this preferred style of reasoning is one which has tended to be associated with the masculine intellect, the antithetical qualities (the emotions, the passions, the affairs of the body) being associated with the feminine persona". ${ }^{82}$ In $R$. v. Kapp the account that succeeds is the one that bears the closest resemblance to this hegemonic masculine ideal.

In the context of Canadian anti-discrimination law, this dualism is not unique to the judicial reasoning in $R v$. Kapp or the Law Court's reasonable person. It has also been reproduced extensively in the legal literature that takes issue with the application and content of the Law test. These broader criticisms become central because this case provided the judiciary with exactly the right ratio of feelings to unfounded discrimination claiming to follow this line of criticism and make the necessary adjustments to the Law test.

The controversy surrounding the Law test is largely tied to Justice Iacobucci's decision to include a consideration of whether or not a policy has offended an equality seeker's dignity on account of the effect it has had on their feelings of self-worth. This, among other concerns, generated a decade of criticism that rendered feelings among the central problems that needed to be solved in the application of the test more broadly. Commentators, myself among them, have pointed to a number of problems with the Law test ranging from its imprecision or malleability, ${ }^{83}$ its imposition of additional evidentiary burdens on litigants ${ }^{84}$ to its use as a mask for judicial discretion. ${ }^{85}$ The most strident of these criticisms, however, has emerged in response to the judiciary's analyses, both actual and hypothetical, of how the alleged discrimination might make litigants feel. While this literature attempts to solve one set of problems, it inadvertently reproduces the gendered dualisms that Smart, Thornton and Naffine all draw attention to in their work.

Donna Greschner has reproduced these gendered dualisms succinctly. Her assessments of the application of the Law test have been widely cited and she was also among the authors cited by the Supreme Court judges in the 2008 R. v. Kapp decision. In her earliest critique, she states unequivocally: "[d]ignity is indeed a feeling as Iacobucci J. notes, but equality rights are legal rights, and law is a discipline of reason and persuasion. The problem with feelings is that no one can argue against them." ${ }^{\circ 6}$ Daphne Gilbert, also among the authors cited by the Kapp Court, directly quoted the last sentence of this passage in her assessment of the Law test. She has taken the criticism further to argue that because Justice Iacobucci's test put the judiciary in the awkward position of having to assess whether or not a reasonable person in the claimant's position would have similar feelings, it left judges with the task of scrutinizing "the objective legitimacy or reasonableness of those feelings." ${ }^{87}$ James Fyfe, another author cited in the

81 Ibid. See also Thornton, supra note 16.

82 Naffine, supra note 16 at 58.

83 James R Fyfe, "Dignity as Theory: Competing Conceptions of Dignity at the Supreme Court of Canada," (2007) 70 Sask

L Rev 1; Donna Greschner, “Does Law Advance the Cause of Equality” (2001) 27 Queen’s LJ 299.

84 Christopher Bredt \& Adam Dodek, "Breaking Law's Grip on Equality: A New Paradign for s. 15" (2003) 20 SCLR 33; Caroline Hodes, "Dignity and the Conditions of Truth: What Equality Needs from Law," (2007) 19:2 CJWL 273.

85 Daphne Gilbert, "Time to Regroup: Rethinking s. 15 of the Charter" (2003) 48 McGill LJ 628; See also Greschner, supra note 80 .

$86 \quad$ Ibid at 313.

87 Gilbert, supra note 82 at 637. 
Kapp Court's 2008 decision, also directly quotes this same passage of Greschner's work in support of his assessment of the role of feelings in the application of the Law test. In his attempt to solve the problem of feelings, however, he also takes issue with Donna Greschner's later work on belonging in order to bring about a return to the Andrews Court's language of "benefits, burdens, disadvantages and opportunities." 88 He considers Greschner's analysis of belonging as something that "ties purpose to feelings" thus replicating the very thing she sought to dismantle in her criticism of the Law test. Fyfe would relinquish dignity and all its attendant feelings in favour of a reasoned approach to vulnerability. But in his attempt to solve the problem, he takes for granted that equality rights cases should address what he refers to as the "ongoing competition for social and economic resources." 89

\section{PRECISELY THE SUBJECT OF $R$. V. KAPP}

It is within this epistemological framework that the testimony of the commercial fishers was assessed as being rife with unruly and unreasonable feelings. Although Greschner claims that nobody can argue against feelings, the $R$. v. Kapp litigation shows otherwise. While both the accused and the fishers that testified on their behalf performed aspects of idealized hegemonic masculinity by exercising their considerable economic and political power, power that propelled their case to the Supreme Court, their feelings ultimately signaled their undoing. As in Justices Brenner, Low and Mackenzie's assessments, their feelings are what took them out of the realm of reality. As a result, two forms of idealized masculinity emerged in this case, each vying for hegemony over the other, and both were dependent on the feminization and racialization of the beneficiaries of the PSP. First, the testimony of the commercial fishers combined with the legal construction of the fishery in the common law generates a neo-Lockean form of protest masculinity characterized by feelings of exclusion from full citizenship that are linked to idealized notions of the commons. Secondly, Justice Brenner and the appellate court decisions that questioned Judge Kitchen's application of fact and law culminated in a return to reason at the Supreme Court that reflects Smart, Thornton and Naffine's conclusions regarding the androcentric presumptions that lie at the heart of successful performances of hegemonic masculinity through legal reasoning.

Naffine situates her critique of legal reasoning in the context of broader challenges to English political theory and practice, particularly liberalism. Her analysis points to the debt that modern western legal reasoning owes to liberal thought. John Locke is often referred to as the father of liberalism. In much the same way as Lockean discourses on property and labour are central to the legal construction of the commons, I have argued elsewhere that the list of grounds in s. 15 of the Charter carries "many of the universalizing Euro-American ontological and epistemological presumptions that are reflective of John Locke's ideas about embodiment, difference and diversity." 90 Together, all of these things ultimately tether judicial reasoning to the logics of colonial modernity in order to guarantee settler futurity in Charter equality rights cases. Locke's work is also rife with gendered contradictions. And while ultimately the combined ideal characteristics of both types of masculinity make an appearance in Locke's work, in the

\footnotetext{
88 Fyfe, supra note 83 at 7.

89 Ibid.

90 Hodes, "Intersectionality", supra note 20.
} 
context of R. v. Kapp they are divided and pit against each other in what Fyfe would refer to as "the ongoing competition over social and economic resources." 91

Although feminist legal scholars have long articulated the multiple ways that hierarchies of masculinity reinforce not only the subordination of women but also the hierarchies between them, a consideration of how this plays out in the relationships between men is relatively new to feminist legal studies. ${ }^{92}$ As Kimberlé Crenshaw and Angela Harris have both articulated, where one gender is dominant, singular or the default gender in single-axis analyses of race, often the gender issues are rendered invisible. ${ }^{93}$ In the almost two decades since Angela Harris called on legal scholars to critically examine the specific role that masculinities play in cases that are assessed on the single-axis of race, a tremendous amount of work has been done on masculinities in legal scholarship more broadly. Nancy Dowd has articulated that one of the valuable contributions of masculinities analysis to feminist legal studies is its exposure of "male complicity in men's subordination of other men." In addition, it reveals "hierarchies between men, particularly those of class and race." 94

The literature on masculinities provides the frameworks through which the hegemonic masculinity articulated in Smart, Thornton and Naffine's respective criticisms of law can be understood. It also provides the necessary frameworks through which the commercial fishers' performance of protest masculinity can be understood. Building on Candace West and Don Zimmerman's insight that gender is not something we have but rather something that we do, Raewyn Connell and James Messerschmidt have defined masculinities as "configurations of practice that are accomplished in social action, and therefore can differ according to the gender relations in a particular social setting." ${ }^{.95}$ Connell has theorized protest masculinity as a process whereby men make claims to power "where there are no real resources for power." 96 In the broader sociological literature, protest masculinities are often described as emerging in response to social marginalization, unequal access to control of the means of production, economic deprivation, feelings of powerlessness, insecurity and anxiety, and/or, as a result of an overinvestment in patriarchal kinship relations that force boys and men into oppositional identities as a response to the absence of father figures. ${ }^{97}$

Karen Pyke characterizes hegemonic masculinity as a glorified ideal type that is embodied by "white, heterosexual middle- and upper-class men who occupy order giving positions in the institutions that they

$91 \quad$ Fyfe Supra note 83 at 7.

92 See Richard Collier, "Masculinities, Law and Personal Life: Toward a New Framework for Understanding Men, Law and Gender" (2010) 33 Harv JL \& Gender 432; Nancy Dowd, "Asking the Man Question: Masculinities Analysis and Feminist Theory" (2010) 33 Harv JL \& Gender 415; Angela P Harris, "Gender, Violence Race and Criminal Justice," (2000) 52 Stan L Rev 777.

93 Ibid at 780.

94 Dowd, supra note 92 at 420.

95 Raewyn W Connell \& James W Messerschmidt, "Hegemonic Masculinity: Rethinking the Concept" (2005) 19:6 Gender \& Society 829 at 836 ; West \& Zimmerman, supra note 18.

96 Connell, Masculinities supra note 18 at 111.

97 Connell, Raewyn, Gender and Power (Stanford, CA: Stanford University Press, 1987); Connell, Masculinities, supra note 18; Talcott Parsons, Essays in Sociological Theory (New York: The Free Press, 1954); Gregory Wayne Walker, "Disciplining Protest Masculinity" (2006) 9:1 Men \& Masculinities 5. 
control."98 Following Pyke's framework, Angela Harris has argued that those who are denied the privileges of hegemonic masculinity, including a proprietary interest in whiteness, resort to hypermasculine compensatory practices such as violence and crime in order claim the manhood that they are denied. ${ }^{99}$ Similarly, in James Messerschmidt's account of the development of oppositional masculinity, he has argued that depending on the context, different men will resort to different crimes in bids to accomplish their masculinity. ${ }^{100}$ According to Harris, the performance of either type of masculinity, whether it be rebellious or hegemonic, is often rooted in the need avoid contamination by femininity through homophobic and misogynistic practices. ${ }^{101}$

Despite Connell and Messerschmidt's explicit articulation of the fluidity and the contextual nature of all masculinities, often both protest and hegemonic masculinities are characterized in such a way that they lead, as in Karen Pyke's formulation, to the reification of ideal types. ${ }^{102}$ This is particularly the case with descriptions of protest masculinity that suggest that material deprivation, or lack of access to the means of production, or single-mother parenting, or the absence of power as domination are among the necessary preconditions to breaking the law or vying for a seat at the hegemon's table. ${ }^{103}$

Connell's account of the multiple expressions of these masculinities, however, is not so simplistic. Although critical of Judith Butler's notions of performativity, Connell's articulation of masculinities as social practices that are changeable and contingent on the context of the gender relations in a given scenario, place or time, harmonizes quite well with Butler's articulation of gender as a performative impersonation of an ideal that nobody actually inhabits. ${ }^{104}$ The difference is that for Butler, gender is never something that can be fully achieved or accomplished. ${ }^{105}$ Sex is subsumed by gender in the sense that if sex accrues social meaning through the attribution of gender, the emergence of gender absorbs and displaces sex. ${ }^{106}$ It is not a given that an identity will emerge on the basis of anatomy and anatomy is neither determinative nor indicative of gender identity or performance. ${ }^{107}$ This is how the commercial fishers and the judiciary, neither of whose membership is exclusively biologically male, could, in the context of $R$. v. Kapp, reify elements of ideal types of protest and hegemonic masculinity, sometimes each overlapping with aspects of the other, while none of them ultimately succeeded in fully accomplishing either one, materially or discursively, through the litigation process.

In this formulation, those who transgress "the masculine heterosexual imperative" by crossing the gender divide and incorporating elements of the feminized set of characteristics are disciplined and regulated based on the value accorded to them in relation to the hegemonic masculine norm. In

98 Karen D Pyke, "Class-Based Masculinities: The Interdependence of Gender, Class and Interpersonal Power" (1996) 10 Gender \& Society 527 at 531 as cited in Harris, supra note 92 at 783.

James W Messerschmidt, Masculinities and Crime: Critique and Reconceptualization of Theory (Lanham, MD: Rowman \& Littlefield, 1993) [Messerschmidt, Masculinities].

Harris Supra note 92.

Parsons, supra note 97; Pyke, supra note 98 at 531; Walker, supra note 97.

See Connell, Masculinities, supra note 18; Richard Collier, Masculinities, Crime and Criminology (London: Sage, 1998); Harris, supra note 92 at 783; Walker, supra note 97.

Liz Kotz, "The Body You Want: An Interview with Judith Butler" (1992) 31 Artforum, 82.

See Butler, Gender Trouble, supra note 18; Butler, Undoing Gender, supra note 18.

Ibid.

Judith Butler, Bodies That Matter: On the Discursive Limits of Sex (New York: Routledge, 1993). 
application, this formula leads to social conditions where feminized subjects who successfully incorporate masculine characteristics increase their value whereas masculine subjects who incorporate feminized characteristics become less valuable. Racialized and classed subjects are also inducted into and implicated in the quest for the materialization of these gendered ideal types. Race and class are, however, often read on the bodies of different people as precluding them from having access to the qualities associated with these normative constructions of gender. In R. v. Kapp those who approximate the hegemonic articulation of masculinity attempt to discipline those who do not. As a result, hierarchies of masculinity create conditions where those who align themselves with hegemonic articulations of masculinity, whatever their gender expression or biological sex, seek the disciplinary authority to regulate those whose masculinity falls outside the limitations of these restrictive criteria.

In the context of $R$. v. Kapp, the commercial fishers knowingly broke the law thereby embodying one of the key aspects of Harris's articulation of rebellious masculinity, Messerschmidt's articulation of oppositional masculinity and Connell's articulation of protest masculinity. ${ }^{108}$ Their testimony reveals that the perceptions that became so problematic for both the Crown, who attempted to impeach them on the grounds of bias and collusion, and the appellate court judges, who questioned their perceptions of reality, were rooted in feelings of injustice and exclusion that were arguably justified given the legal construction of the formal equality right of public access to the fishery manufactured in the common law. In order to distinguish themselves from the beneficiaries of the PSP and shore up their bids to achieve masculinity and by extension, full citizenship and the fish, the accused and the defense witnesses deliberately racialized and emasculated the beneficiaries of the PSPs.

Significantly, Judge Kitchen began his analysis of the evidence of discrimination with the settler nativism present in Robert McKamey's testimony. This choice grounded all of the subsequent testimony in a patrilineal narrative. This narrative, like the biologically deterministic bloodlines submission introduced by Judge Kitchen in his assessment of the comparator group chosen by the accused, created out of commercial fishing an immutable characteristic inherited through the paternal line. ${ }^{109}$ Fisherman, in combination with the masculine pronoun reinforced this gender default in all of the witness testimony. This suggests that whatever the biological sex or gender identity of any given fisher outside of their profession, masculinity is the gender expression of commercial fishing. The ability to successfully compete for the fish on a formal equality playing field becomes the standard by which the achievement of full masculinity can be measured.

But, this is not all that is being measured in the discursive construction of the masculine fishery. So too is one's citizenship. Like fishing, citizenship is gauged on the basis of one's ability to exercise the independence and individualism associated with the hegemonic masculine norm. Defense witness Debra Logan, who was identified as having rejected both her status as a member of the Sto:lo Nation and her ability to participate in the PSP, articulated this perspective most directly in her testimony when asked to comment on the relationships between the fishers after the PSPs had first been initiated in 1992:

After that date when an Indian fisherman comes to the harbor with a boatload of fish there is the automatic assumption that he's gotten it the easy way. He's been allowed to fish in places where no other fisherman is allowed to go. One of the terms I hear used around the

108 Connell, Masculinities, supra note 18; Harris, supra note 88 at 783; Messerschmidt, Masculinities, supra note 100.

109 Kapp Provincial Court, supra note 8 at paras 91 and 92. 
docks is...he's one of the chosen ones." I hear that quite a lot... They were looked down on, sneered at, demeaned by this assumption that they weren't good fishermen. You don't need to be because the government's there to prop you up, and it's been an extremely demoralizing and demeaning thing for Indian fishermen. [...] I don't need the government's help. There's nothing wrong with me. I'm quite capable of functioning as a Canadian without special help. ${ }^{110}$

Logan's association of high skill levels with the ability to fish in the absence of measures that were arguably designed to achieve equity and redress the effects of colonial policy, reproduces a highly individualistic, gendered ideal of ability that is linked to citizenship across a range of the defense witness testimony. In this passage, she switches from other to self in order to distinguish her own capabilities from the "chosen ones." In her formulation of fairness, to be the beneficiary of a remedial government program draws not only one's skill into question but also the ability to embody a series of stereotypically masculine characteristics such as competition and independence, all of which become essential to her ability to exercise full citizenship. In order to lay claim to the resource, a process of racialized emasculation takes place in her testimony. Indian-ness becomes associated with low skill levels and Logan can distance herself from both these bad fishermen and any contamination of her individualistic sense of achievement with the feminized qualities of interdependence, redress and remedy through the rejection of her own status and ability to participate in the PSP under a communal license.

Combining McKamey's construction of the masculine fishery as patrilineal inheritance with Logan's practice of racialized emasculation, other defense witnesses also made connections between fishing and the exercise of idealized forms of citizenship. In his testimony, Michael Forrest also articulates his experience through practices of self and other identification that foreground his feelings of loss. In his testimony, access to the fishery becomes equivalent to citizenship:

You found that you were on the beach watching other people fish commercially that was based on their ethnic origin and somehow you weren't a part of it. To describe this feeling is a difficult item, and I've spoken to many, many fishermen about this because if you grew up in the fishery, and it was part of your heritage, and it was suddenly ripped from you, the feeling that you were suddenly less of a Canadian in the process or something less than average is welled up pretty much, and it still is repugnant to most of us that I know about...111

Similarly, Donna Sonnenberg also engaged in practices of identification that equate access to the fishery with her own citizenship status: "I feel like I'm half a Canadian because I feel like I've had my rights removed from me. I don't see us having our own special fishery at certain times with no Indians in them". 112

110 Ibid at paras 120 and 121 .

111 Ibid at para 106.

112 Ibid at para 97. 
Although the Supreme Court of Canada characterized human dignity as the "lodestar" guiding the protection of Charter rights in this case, they jettisoned the dignity interest from the Law test and with it, all of the messy feelings and perceptions of these defense witnesses. ${ }^{113}$ Their return to the earlier Andrews v. Law Society of $B C$ framework for equality rights analysis under s. 15 (1) of the Charter, however, was no less gendered. The Supreme Court judges returned to reason by leading their list of citations with Donna Greschner's criticisms of the deployment of feelings through the Law test. They grounded their reasons in this epistemological framework and decided that even with the guidance of the contextual factors of the case, the feeling of "human dignity is an abstract and subjective notion" that has also "proven to be an additional burden on equality claimants, rather than the philosophical enhancement it was intended to be." 114 Following the Tsawwassen First Nation's intervention on appeal and Justice Kirkpatrick's reasons at the BC Court of Appeal, Justice Michel Bastarache, however, delivered a different set of reasons. While he concurred with the majority on the restatement of the test for the application of s. 15 (1) and the elaboration on the meaning of s. 15 (2), he concluded that s. 25 of the Charter provided a full answer to the claim. In his assessment, s. 25 operates as a shield to bar discrimination claims that challenge Aboriginal rights within the meaning of s. 35 (1) of the Constitution Act. ${ }^{115}$

In the end, rather than enlarging what Bastarache, J. referred to as "the reach of measures needed to fulfill the promise of reconciliation," the Supreme Court engaged in a series of compromises that resulted in the discursive resettlement of the fisheries as a state regulated Lockean common property resource in need of an ameliorative program. ${ }^{116}$ Reinforcing the defense counsel's original argument that the PSP resulted in workplace discrimination, they reframed the program as one that was designed to ameliorate disadvantage. This strategy maintained the constitutionality of the programs negotiated as part of the AFS, but, despite granting these programs independent status, the decision failed to challenge the erroneous characterization of PSPs as "race-based." As a result, the decision indirectly racialized the beneficiaries of the programs in order to fulfill the grounds requirement for immutable characteristics under s. 15 of the Charter.

\section{CONCLUSION: THE RETURN TO REASON IN R. V. KAPP?}

The commercial fishers in this case successfully mobilized themselves as a cohesive community with enough political power to influence public discourse at the same time as they managed to garner the legal and financial support to propel their case to the Supreme Court of Canada. While this kind of privilege may result in successfully securing a hearing and in some short-lived victories in court, as exemplified by the BC Provincial Court ruling, it is no guarantee that these kinds of claims will result in the desired outcome for the claimants. In the end, the commercial fishers failed to show that they had experienced discrimination and they lost their case. The outcome, therefore, betrays any certainty that economic advantage alone will necessarily guarantee that politically powerful groups of people can successfully use the law to secure their own immediate or longer-term personal interests. Nevertheless, the legal

113 Kapp SC, supra note 3 at para 21.

114 Ibid at para 22.

115 Ibid beginning at para 67.

116 Ibid at para 116. 
developments that emerged in connection with ss. 15 and 25 of the Charter rest on the preservation of the androcentric dualisms that remain at the heart of legal reasoning and the preservation of the Lockean commons. R. v. Kapp, therefore, provides a case study in the epistemological foundations and reach of contemporary colonial discourse.

The aftermath of this case reveals that the indirect restatement of terra nullius through the commons is still very much alive in the present. Since R.v. Kapp was decided in 2008, Lockean conceptions of the commons remain foundational to both popular understandings of the fisheries and their management. The Cohen Commission's final report explicitly identifies the Pacific Sockeye Salmon fisheries in terms of the common law framework for regulated common property resources. Despite outlining the DFO's Aboriginal Aquatic Resources and Oceans Management Program that has, since 2004, allotted between six and seven million dollars per year to build capacity for successful co-management regimes with First Nations, the Commission's recommendations are not sympathetic to co-management regimes. ${ }^{117}$

Among the report's many recommendations, two are of particular importance to the fishery's management. The first is that the Fraser River salmon fishery should be centrally managed by the federal government and that ultimate decision-making authority should be held by the federal minister of fisheries and oceans. In 2015, the Ministry of Fisheries and Oceans implemented an allocation framework whereby shares for First Nations commercial fishers would be based on voluntarily relinquished licenses and both commercial fishers and First Nations would be responsible for determining the best approach to harvesting their shares of the fishery. Questions remain about whether or not these approaches have altered the perception of the formal equality right of public access, whether commercial fishing should be a matter of right at all, and whether the ways of understanding and implementing conservation, stewardship and management within and between different Indigenous communities and the DFO can be combined in ways that might better serve all of the goals of conservation, fisheries management, the exercise of plural sovereignties and self-government.

The second recommendation is to develop a clear definition of food, social and ceremonial fishing. This recommendation has not yet been implemented. With regard to fisheries infractions, media reports continue to routinely cover stories of Indigenous fishers who are criminally sanctioned for attempting to exercise their rights on the Fraser River. This is something that Ernie Crey, a former fisheries advisor for the Stó:lo Nation, has identified can be problematic for the Indigenous fishers in the Lower Fraser River region. Five years after Kapp was decided, Indigenous fishers were still being charged with minor fisheries infractions and in 2015 Rachel Bergen profiled the Wild Salmon Caravan, a collaborative grassroots project designed to bring awareness to and defend traditional fishing rights in the region. ${ }^{118}$ Despite court decisions recognizing Indigenous rights, measures have not yet been put into place that would effectively guarantee them. ${ }^{19}$

117 Cohen Commission, supra note 73.

118 Rachel Bergen, “Aboriginal Fishers Defend Traditional Right to Salmon in Fraser Valley,” Ricochet (1 May 2015), online: < https://ricochet.media/en/428/aboriginal-fishers-defend-traditional-right-to-salmon-in-fraser-valley>.

11 David Pall, "Woman Cleared of Charges but Analysts Cry Legal 'Humiliations"” (2013) 31:4 Windspeaker, online: $<\mathrm{http}: / /$ www.ammsa.com/publications/windspeaker/woman-cleared-charges-analysts-decry-legal-

$\%$ E2\%80\%98humiliations $\%$ E2\%80\%99>. 
One of the most troubling of these fisheries infractions cases was moving through the courts at the same time as the Kapp litigation. The Stó:lo Nation's Kwitsel Tatel (Patricia Kelley) has been profiled in several mainstream news media sources. ${ }^{120}$ She had been criminally charged for illegally possessing and selling some of the roughly four-hundred Sockeye that she had caught and packed on ice in 2004 for ceremonial purposes. This, however, marked only the beginning of a nearly ten-year legal odyssey. It was not until 2013 that a court ordered that she be awarded an absolute discharge and paid damages in the amount of $\$ 2,500 .{ }^{121}$ The juxtaposition of her case with the claims of the commercial fishers in $R$. v. Kapp highlights the many obstacles to both reconciliation and access to justice that reach far beyond the limited scope of either this article or this case. She was arrested for alleged fisheries infractions one year after the Provincial Court judge successfully mobilized a series of colonial judicial decisions that supported a civil defense of an idealized Lockean commons. Despite the reversals in outcome that took place in both of these cases, neither of them can be understood in terms of access to justice.

The Kapp Court also maintained a s. 15 legal framework for understanding discrimination that continues to work in ways that deny potential litigants access to the courts. The grounds requirement in Charter applications still requires litigants to identify immutable personal characteristics, whether actual or constructed, as either the causes of the discrimination under s. 15(1) or as the basis of targeted ameliorative programs under s. 15(2). Despite the vast criticism articulating that Justice Iaccobucci's introduction of the dignity interest was what placed undue burden on litigants, the aftermath of R. v. Kapp reveals that, combined with the financial costs of litigation, it is within the grounds inquiry that many of the real burdens lie.

Since the Kapp Court's re-articulation of the grounds approach, the Court has moved away from the comparator groups that led to the construction of commercial fishing as an analogous ground of discrimination in this case. ${ }^{122}$ Nevertheless, in subsequent cases litigants have attempted to plead that poverty is an analogous ground. As documented in Jessica Eisen's work, however, the courts often decide that because poverty is not an immutable characteristic, but rather a social condition, these claims either fail or are assessed as not warranting full consideration in the courts. ${ }^{123}$ Central to the justification for denying these kinds of claims is the conclusion that poverty is something that people desire to change, can change, and under certain circumstances, succeed in changing. The first problem with this approach is the presumption that because poverty is changeable, the people living in poverty are responsible for their poverty. The second is the erasure of how poverty is both racialized and gendered across Canada. ${ }^{124}$

120 Mark Hume, “After 200 Court Appearances, Sto:lo Woman is Free to Fish Again”, The Globe and Mail (29 May 2013), online: $<\mathrm{http}: / / \mathrm{www}$.theglobeandmail.com/news/british-columbia/after-200-court-appearances-stolo-woman-is-free-tofish-again/article12213412/>; Pall, supra note 114.

121 Ibid.

122 Alberta (Aboriginal Affairs and Northern Development) v Cunningham [2011] 2 SCR 37; Corbiere, supra note 2 at 14; Kapp SC, supra note 3; Withler, supra note 15.

123 Eisen, "Shaky Grounds", supra note 15.

124 Canadian Women's Foundation, "The Facts about Women and Poverty" (2017) online: < http://www.canadianwomen.org/facts-about-women-and-poverty>; Sui-Ming Kwok \& Maria A Wallis, Daily Struggles: The Deepening Racialization and Feminization of Poverty in Canada (Toronto: Canadian Scholars Press, 2008); Susan Scott, All Our Sisters: Stories of Homeless Women in Canada (Toronto: University of Toronto Press, 2008); Statistics Canada. Canadian Income Survey, persons in low income Canada and Provinces (2012), online:

$<$ http://www5.statcan.gc.ca/cansim/a26?lang=eng\&retrLang=eng\&id=2060003\&pattern=low+income\&tabMode=dataTa 
Despite Eisen's later work advocating for relational approaches to equality doctrine by drawing attention to the Supreme Court's tacit move away from the Corbiere Court's formalistic approach to the grounds in Taypotat, the problem with the grounds approach cannot be resolved by simply exchanging immutability with relationality. ${ }^{125}$ Louis Taypotat brought an application for judicial review of the Kahkewistahaw Election Act after having been denied the opportunity to run as a candidate for Chief because he did not have the required level of education. This was despite having been Chief for twentyseven years prior and having played an instrumental role in the thirteen-year community consultation process that led to the development of the community elections code that eventually led to his exclusion as a candidate. Taypotat listed ten possible grounds, one of which was "residential school survivors without a grade twelve education." 126 On appeal and on its own initiative, however, the Federal Court allowed his s. 15 claim but chose instead "older community members who live on reserve" as the analogous ground. ${ }^{127}$ In a unanimous decision, the Supreme Court of Canada dismissed his s. 15 claim first, because residence on reserve had not been recognized as an analogous ground previously, and second, because the record "offered "virtually no evidence about the relationship between age, residency on a reserve and education in the Kahkewistahaw First Nation to demonstrate that the provisions burdened a disadvantaged group." 128

While Eisen's conclusion that doctrine ought to shift in ways that attend to relationship is well taken, Taypotat does not provide an adequate framework for such an approach. In this case, while immutability was not explicitly stated as a requirement for establishing his grounds, the relationships that were considered were not Taypotat's role in the community, the impact of the legislation, or the longer-term consequences for him or the community. Rather, despite articulating that the analysis should focus on the social and economic context in which the claim of inequality arises, the grounds approach still circumscribed its relational potential. The relationship that became the focus of the inquiry was between Taypotat's age and educational level and whether or not these could be generalized to become a set of personal characteristics belonging to a group in his community. ${ }^{129}$ Here again, the first step of the inquiry locates the cause of the discrimination in the group before discussing the nature of the distinction or its effects.

Eisen also discusses her proposed relational shift as one small piece of a larger puzzle. She does not, however, address settler colonialism as part of that puzzle. Kapp reveals that colonial epistemologies and the discourse that manifests them materially not only through law, but in a broad range of institutional contexts, are among the pieces of the larger puzzle that should have been addressed. There is no doctrinal fix that will resolve any of what I have identified here. But before any discussion of relationality can become meaningful in colonial contexts, they must be acknowledged as such. The history of the Charter cannot be divorced from either the fact that residential schools were still in operation at the time of the

ble\&srchLan=-1\&p1=1\&p2=-1>. See also Tanudjadjal $v$ Attorney General of Canada [2015] CANLII 36283

(Application for Leave to Appeal) online: SCC < https://scc-csc.lexum.com/scc-csc/scc-l-csc-a/en/item/15426/index.do>

125 Jessica Eisen, "Grounding Equality in Social Relations: Suspect Classification, Analogous Grounds and Relational Theory," (2017) 42:2 Queen's LJ 41.

126 Kahkewistahaw First Nation v Taypotat [2015] 2 SCR 548 at para 12.

127 Ibid at para 26.

128 Eisen "Grounding Equality" Supra note 125 at p. 59; Ibid at paras 24 and 26.

129 See Hodes, "Intersectionality", supra note 20 for an overview of how this approach reproduces another set of Lockean discourses on identity, difference and diversity. 
patriation of the Canadian constitution or the legacies of Trudeau and Chrétien's now infamous White Paper, among many other things. Kapp and its aftermath demand no less than a seismic epistemological shift that will alter the foundations of the Canadian legal landscape and all Canadian institutional cultures. If it is doctrine that Eisen believes to be a fruitful place for change, its colonial roots cannot be ignored. Judge Kitchen was doing his job and he had at his disposal everything he needed because the colonial frameworks had already been decided at law. Perhaps rather than focusing on equality rights doctrine exclusively, transforming the doctrine of stare decisis and its constant reinstatement of the colonial past into the ongoing colonial present should be part of a larger multi-pronged approach to meeting the recommendations of the TRC.

In the aftermath of $R$. v. Kapp, contemporary restatements of terra nullius through the legal construction of the fisheries as common property resources, the many foreclosures on poverty claims that routinely occur in the courts and the focus on the claimant group as distinct from the discrimination are not mutually exclusive phenomena. They are all racialized, gendered and maintained through discourse that tethers Canadian laws, policy, practice and public opinion to the logics of colonial modernity. The protest fishery that initiated this case took place in 1998, the same year that the federal government released a statement of reconciliation as a result of the findings of the Royal Commission on Aboriginal Peoples. The Supreme Court decision was rendered in the same year that former Prime Minister Stephen Harper made his apology for residential schools. Ten years later, in the wake of the TRC's recommendations regarding colonial policy and practice, a closer look at Canadian anti-discrimination law's investment in settler colonialism and a gendered and racialized settler futurity is long overdue. 